\title{
Time-Varying COVID-19 Reproduction Number in the United States
}

\author{
Douglas D. Gunzler, PhD
}

Ashwini R. Sehgal, MD

Population Health Research Institute, MetroHealth Medical Center, Cleveland, Ohio

\begin{abstract}
The basic reproduction number is the average number of people to whom an infected person transmits the infection when virtually all individuals in a population are susceptible. We sought to calculate the current reproduction number for COVID-19 for each state in the United States. For the entire United States, the time-varying reproduction number declined from 4.02 to 1.51 between March 17 and April 1, 2020. We also found that the time-varying reproduction number for COVID-19 has declined in most states over the same two week period which suggests that social isolation measures may be having a beneficial effect.
\end{abstract}


medRxiv preprint doi: https://doi.org/10.1101/2020.04.10.20060863; this version posted April 15, 2020. The copyright holder for this preprint (which was not certified by peer review) is the author/funder, who has granted medRxiv a license to display the preprint in perpetuity. All rights reserved. No reuse allowed without permission.

Time-Varying COVID-19 Reproduction Number in the United States

\section{Introduction}

The basic reproduction number is the average number of people to whom an infected person transmits the infection when virtually all individuals in a population are susceptible. A reproduction number greater than 1.0 means an epidemic is growing while a number less than 1.0 means an epidemic is slowing down and may eventually end. The reproduction number for the novel coronavirus responsible for COVID-19 was estimated to be 2.2 in Hubei Province, China, based on cases in December 2019 and January 2020.(1) Following one month of social distancing and lockdown, the reproduction number decreased to 1.6.(2) We sought to calculate the current reproduction number for each state in the United States.

\section{Methods}

We used data on the number of daily cases as compiled by the New York Times from federal, state, and local sources to estimate reproduction number for the most recent day, one week earlier, and two weeks earlier.(3) This estimation requires information on the distribution of the serial interval, i.e. the time between symptom onset in an infector-infectee pair. We utilized serial interval data reported in China and truncated negative values and values greater than 20 days as unrealistic.(4) We identified the best function as a gamma distribution with a mean of 4.5 and a standard deviation of 4.3 days and calculated time dependent daily reproduction numbers over a 14 day interval using the approach proposed by Wallinga \& Teunis with a Bayesian modification for real-time estimation.(4-6) All analyses were performed with $\mathrm{R}$ statistical software and $\mathrm{R} 0$ and projections packages.

\section{Results}

For the entire United States, the reproduction number declined from 4.02 to 1.51 over the last two weeks (Table). Individual states varied greatly in their current reproduction number and trajectory over the last two weeks. For example, Ohio's reproduction number declined from 3.97 to 1.62. By contrast, Louisiana had a more gradual decline and had a reproduction number on April 1 of 2.22.

Even small differences in reproduction number can have sizeable effects. For example, Ohio will be projected to have 3500 incident cases in three weeks if the current reproduction number 
medRxiv preprint doi: https://doi.org/10.1101/2020.04.10.20060863; this version posted April 15, 2020. The copyright holder for this preprint

(which was not certified by peer review) is the author/funder, who has granted medRxiv a license to display the preprint in perpetuity.

All rights reserved. No reuse allowed without permission.

Time-Varying COVID-19 Reproduction Number in the United States

of 1.62 persists. The projected number of cases would be 1400 with a reproduction number of 1.40 and 6500 with a reproduction number of 1.80 .

\section{Discussion}

Several factors influence the value of the reproduction number, including how contagious an infectious organism is, how many susceptible people there are and their proximity to each other, and what measures are implemented to limit spread. We found that the reproduction number for COVID-19 has declined in most states over the past two weeks which suggests that social isolation measures may be having a beneficial effect. However, most states still have reproduction numbers substantially higher than 1.0. That means it would be premature to relax restrictions and resume normal social and economic activities. Doing so now will result in an increase in the reproduction number and a surge of new cases. Examining changes in reproduction number over the coming weeks and months may help guide decisions to continue social restrictions and to monitor the impact of gradually relaxing such restrictions.

Many COVID-19 cases, particularly asymptomatic and mild ones, are not reported to public health departments so our calculation may underestimate the true reproduction number. In addition, the number of people tested has increased greatly in recent days as testing kits have become more available. This would be expected to increase COVID-19 diagnoses and therefore the reproduction number. It is encouraging that we found a reduction in reproduction number despite this increase in testing. Other limitations include the lack of United States data on serial intervals, daily reproduction numbers can be highly variable and the small numbers of cases in some states.

\section{Acknowledgments}

This study was supported in part by grants UL1 TR002548 and U54 MD002265 from the National Institutes of Health. 
medRxiv preprint doi: https://doi.org/10.1101/2020.04.10.20060863; this version posted April 15, 2020. The copyright holder for this preprint (which was not certified by peer review) is the author/funder, who has granted medRxiv a license to display the preprint in perpetuity. All rights reserved. No reuse allowed without permission.

Time-Varying COVID-19 Reproduction Number in the United States

\section{References}

1. Li Q, Guan X, Wu P, et al. Early transmission dynamics in Wuhan, China, of novel coronavirus-infected pneumonia. New Engl J Med. 2020;382:1199-1207.

2. Zhang Y, Jiang B, Yuan J, Tao Y. The impact of social distancing and epicenter lockdown on the COVID-19 epidemic in mainland China: a data-driven SEIQR model study. Available at https://www.medrxiv.org/content/10.1101/2020.03.04.20031187v1.full.pdf Accessed April 4, 2020.

3. New York Times COVID-19 data. Available at https://github.com/nytimes/covid-19-data Accessed April 2, 2020.

4. Du Z, Xu X, Wu Y, Wang L, Cowling BJ, Meyers LA. Serial interval of COVID-19 among publicly reported confirmed cases. Emerg Infect Dis. March 19, 2020. Available at https://wwwnc.cdc.gov/eid/article/26/6/20-0357 article Accessed April 2, 2020.

5. Wallinga J, Teunis $P$. Different epidemic curves for severe acute respiratory syndrome reveal similar impacts of control measures. Am J Epidemiol. 2004;160:509-516.

6. Cauchemez S, Boëlle PY, Thomas G, Valleron AJ., 2006. Estimating in real time the efficacy of measures to control emerging communicable diseases. Am J Epidemiol. 2006;164:591-597. 
medRxiv preprint doi: https://doi.org/10.1101/2020.04.10.20060863; this version posted April 15, 2020. The copyright holder for this preprint

(which was not certified by peer review) is the author/funder, who has granted medRxiv a license to display the preprint in perpetuity. All rights reserved. No reuse allowed without permission.

Time-Varying COVID-19 Reproduction Number in the United States

Table. Time varying COVID-19 reproduction number over the last two weeks in the United States.

Reproduction Number (95\% Confidence Interval) Number of incident cases

$\begin{array}{lll}\text { March } 17 & \text { March 24 } & \text { April 1 }\end{array}$

\begin{tabular}{|c|c|c|c|}
\hline United States & $4.02(3.69,5.15) 4063$ & $1.73(1.47,1.86) 16988$ & $1.51(0.69,1.96) 26568$ \\
\hline Alabama & $4.41(3.69,5.15) 27$ & $1.67(1.47,1.86) 152$ & $1.26(0.69,1.96) 107$ \\
\hline Alaska & $3.22(1.72,4.81) 3$ & $1.40(0.88,1.97) 10$ & $0.91(0,1.82) 10$ \\
\hline Arizona & $5.09(3.99,6.18) 19$ & $1.85(1.53,2.17) 106$ & $0.88(0.59,1.23) 115$ \\
\hline Arkansas & $4.69(3.93,5.53) 29$ & $1.12(0.91,1.34) 43$ & $1.37(0.82,2) 60$ \\
\hline California & $3.16(2.96,3.36) 174$ & $1.93(1.82,2.05) 877$ & $1.56(1.43,1.69) 1234$ \\
\hline Colorado & $4.30(3.81,4.81) 62$ & $1.90(1.69,2.12) 346$ & $1.32(1.1,1.55) 356$ \\
\hline Connecticut & $4.34(3.86,4.82) 63$ & $1.87(1.71,2.03) 137$ & $1.21(1.04,1.38) 429$ \\
\hline Delaware & $2.51(1.75,3.3) 4$ & $1.79(1.16,2.48) 24$ & $1.61(1.02,2.32) 49$ \\
\hline District of Columbia & $8.15(7.21,9.27) 32$ & $1.58(1.24,1.91) 36$ & $1.00(0.84,1.16) 91$ \\
\hline Florida & $3.08(2.85,3.32) 108$ & $2.06(1.95,2.19) 512$ & $1.47(1.32,1.61) 1024$ \\
\hline Georgia & $4.30(3.92,4.71) 89$ & $1.85(1.69,2.01) 256$ & $1.45(1.34,1.58) 631$ \\
\hline Hawaii & $7.21(5.67,9.27) 10$ & $1.70(0.5,2.98) 11$ & $1.75(0.77,2.81) 34$ \\
\hline Idaho & $8.29(6.7,10.82) 12$ & $2.33(1.96,2.73) 66$ & $2.34(1.84,2.85) 143$ \\
\hline Illinois & $3.09(2.86,3.3) 134$ & $2.08(1.93,2.24) 663$ & $1.66(1.5,1.82) 986$ \\
\hline Indiana & $4.96(3.89,5.95) 17$ & $2.43(2.14,2.72) 177$ & $1.71(1.46,1.95) 406$ \\
\hline lowa & $3.18(2.29,4.01) 6$ & $2.22(1.59,2.83) 34$ & $0.99(0.55,1.45) 51$ \\
\hline Kansas & $4.61(3.5,5.77) 13$ & $2.05(1.62,2.56) 39$ & $1.25(0.75,1.76) 54$ \\
\hline Kentucky & $3.56(2.75,4.46) 12$ & $1.94(1.51,2.36) 50$ & $1.59(1.2,2.04) 92$ \\
\hline Louisiana & $3.59(3.29,3.88) 112$ & $1.90(1.76,2.04) 510$ & $2.22(2.08,2.36) 1187$ \\
\hline Maine & $2.55(1.87,3.28) 9$ & $1.56(1.09,2.07) 13$ & $1.66(0.73,2.55) 41$ \\
\hline Maryland & $3.09(2.61,3.57) 23$ & $2.53(2.16,2.9) 158$ & $1.90(1.6,2.22) 323$ \\
\hline Massachusetts & $4.52(4.04,4.96) 72$ & $2.04(1.94,2.14) 579$ & $1.65(1.49,1.83) 1118$ \\
\hline Michigan & $2.71(2.56,2.86) 214$ & $1.97(1.85,2.09) 584$ & $2.12(1.95,2.29) 1663$ \\
\hline Minnesota & $2.96(2.36,3.58) 12$ & $1.62(1.14,2.13) 59$ & $1.19(0.58,1.83) 60$ \\
\hline Mississippi & $4.04(3.25,4.83) 16$ & $1.67(1.33,2) 110$ & $1.69(1.2,2.24) 106$ \\
\hline Missouri & $6.28(4.94,7.83) 14$ & $1.99(1.76,2.23) 130$ & $1.57(1.34,1.83) 230$ \\
\hline Montana & $3.64(2.58,4.89) 7$ & $2.12(1.42,2.83) 25$ & $1.08(0.24,1.94) 19$ \\
\hline Nebraska & $2.34(1.62,3.24) 4$ & $2.19(1.06,3.37) 8$ & $3.43(0.64,6.38) 56$ \\
\hline Nevada & $3.22(2.71,3.7) 17$ & $1.88(1.6,2.15) 130$ & $1.69(1.11,2.29) 166$ \\
\hline New Hampshire & $2.31(1.66,2.93) 5$ & $1.77(1.33,2.27) 21$ & $1.34(0.77,2.02) 48$ \\
\hline New Jersey & $4.26(4.04,4.48) 308$ & $2.54(2.42,2.65) 2474$ & $1.82(1.71,1.94) 3559$ \\
\hline New Mexico & $3.61(2.47,4.94) 7$ & $2.11(1.34,3) 24$ & $1.68(0.9,2.55) 48$ \\
\hline New York & $4.30(4.2,4.4) 1770$ & $1.39(1.36,1.42) 5921$ & $1.21(1.17,1.26) 8057$ \\
\hline North Carolina & $3.70(3.18,4.25) 38$ & $1.55(1.36,1.72) 75$ & $0.36(0.23,0.52) 54$ \\
\hline North Dakota & $7.47(6.18,9.27) 12$ & $2.14(1.24,3.03) 13$ & $1.86(0.6,3) 21$ \\
\hline Ohio & $3.97(3.36,4.57) 30$ & $1.94(1.71,2.17) 161$ & $1.62(1.32,1.92) 348$ \\
\hline Oklahoma & $3.09(2.43,3.84) 15$ & $2.25(1.9,2.59) 84$ & $2.76(2.04,3.42) 153$ \\
\hline Oregon & $4.21(3.35,5.28) 13$ & $1.85(1.54,2.18) 50$ & $0.76(0.43,1.15) 46$ \\
\hline Pennsylvania & $3.98(3.52,4.47) 48$ & $2.41(2.24,2.59) 539$ & $1.47(1.32,1.63) 808$ \\
\hline Rhode Island & $3.13(2.37,3.91) 11$ & $2.35(1.24,3.57) 33$ & $1.44(0.96,1.98) 78$ \\
\hline South Carolina & $4.35(3.57,5.15) 21$ & $1.62(1.38,1.91) 32$ & $1.99(1.61,2.42) 210$ \\
\hline South Dakota & $3.64(2.77,4.86) 3$ & $1.84(1.13,2.59) 5$ & $2.17(0.00,4.37) 21$ \\
\hline Tennessee & $4.65(4.12,5.23) 57$ & $1.82(1.57,2.09) 197$ & $1.88(1.67,2.11) 606$ \\
\hline Texas & $3.63(3.31,3.97) 82$ & $2.14(1.96,2.3) 424$ & $1.95(1.72,2.17) 685$ \\
\hline Utah & $3.62(2.87,4.34) 15$ & $1.75(1.4,2.12) 56$ & $1.59(1.07,2.2) 125$ \\
\hline Vermont & $3.52(2.27,4.74) 3$ & $1.53(1.11,1.99) 35$ & $1.11(0.55,1.79) 28$ \\
\hline Virginia & $4.16(3.28,5.06) 16$ & $2.28(2.01,2.53) 213$ & $2.06(1.74,2.41) 261$ \\
\hline Washington & $3.54(3.33,3.77) 202$ & $1.86(1.59,2.13) 623$ & $0.87(0.5,1.26) 296$ \\
\hline West Virginia & $5.78(3.09,9.27) 3$ & $1.92(1.14,2.69) 25$ & $1.89(0.89,3.3) 29$ \\
\hline Wisconsin & $3.45(3.06,3.88) 49$ & $1.55(1.35,1.75) 131$ & $1.91(1.28,2.49) 199$ \\
\hline Wyoming & $3.20(1.55,5.15) 1$ & $1.77(1.14,2.48) 7$ & $1.55(0.82,2.45) 17$ \\
\hline
\end{tabular}

